"This is an Author's Accepted Manuscript of an article published in Applied Economics, Vol. 43, Issue 26, October 2011, pp.3775-3788, [copyright Taylor \& Francis], available online at: http://www.tandfonline.com/doi/abs/10.1080/00036841003724411." 


\title{
Determinants of ICT adoption: Evidence from firm-level data
}

\author{
Stefanie A. Haller and Iulia Siedschlag ${ }^{\dagger}$ \\ Economic and Social Research Institute, Dublin
}

\begin{abstract}
We analyse factors driving inter- and intra-firm diffusion of ICT using data from Irish manufacturing firms over the period 2001-2004. We find that the path of ICT diffusion has been uneven across firms, industries and space, which is consistent with the theory of new technology adoption. Our results suggest that firms which are larger, younger, fast-growing, skill-intensive, export-intensive and firms located in the capital city region have been relatively more successful in adopting and using ICT. We find positive technology spillovers from firms that have adopted ICT located in the same industry and region.
\end{abstract}

Keywords: $\quad$ ICT diffusion, human capital, industrial structure, technology spillovers.

JEL classification: L21, O31, O33

† Correspondence: Economic and Social Research Institute, Whitaker Square, Sir John Rogerson's Quay, Dublin 2, Ireland. Telephone: +353-1-8632000; Fax: +353-1-8632100; Stefanie.Haller@esri.ie; Iulia.Siedschlag@esri.ie. 


\section{$1 \quad$ Introduction}

There is growing evidence suggesting that Information and Communication Technologies (ICT) are strong determinants of productivity growth differentials as well as the ability of countries to benefit from globalisation (Jorgenson and Stiroh, 2000; Oliner and Sichel, 2000; Bassanini and Scarpetta, 2002; OECD, 2004; Timmer and van Ark, 2005). In addition, existing empirical evidence shows that ICT use contributes to productivity and output growth at the firm level (Lehr and Lichtenberg, 1999; Brynjolfsson and Hitt, 2000, 2003; Matteucci et al. 2005).

In this paper we analyse the patterns and determinants of ICT diffusion at the firm level. We add to the existing empirical literature in two ways. First, in comparison to most of existing empirical studies we estimate theory based models to test the effects of firm heterogeneity and information spillovers on ICT diffusion. Second, in contrast to existing cross-section studies we use a novel panel data set from manufacturing firms in Ireland which allows us to uncover the ICT diffusion path over time and to alleviate potential endogeneity arising from simultaneity and omitted variable bias.

Uncovering the factors driving ICT diffusion is important and relevant for both research and policy. First, in contrast with a well established theoretical literature on new technology diffusion, firm-level empirical evidence on ICT diffusion is still limited. Second, from the policy perspective, to the extent that a wide and fast diffusion of ICT is desirable, it is essential to understand what factors are likely to increase the diffusion of ICT.

The diffusion of new technology is likely to vary across countries depending on country specific characteristics such as economic size, distance to the technological frontier, domestic absorptive capacity, economic specialisation and openness to trade and investment (Keller 2004). The case of ICT diffusion in Ireland is interesting given 
its specialisation in ICT industries ${ }^{1}$ together with a high degree of openness to trade and investment. In addition, Ireland has both firms that are close to and far from the technological frontier. According to the European Commission (2009) Ireland ranks highly among the European Union member states with respect to e-commerce (ranked first on the percentage of enterprises purchasing online, ranked third on the percentage of enterprises selling online and on e-commerce as per cent of total turnover), ebusiness (ranked second on the share of enterprises using applications for integrating internal business processes).

Our results suggest that the path of ICT diffusion has been influenced by firm characteristics such as firm size, age, skill intensity, international competition and proximity to early adopters of ICT in the same industry and region.

The remainder of this paper is structured as follows. Section 2 discusses the analytical framework for our empirical analysis and testable hypotheses about the factors driving ICT diffusion across firms, industries and regions. In Section 3, we describe our data set, the ICT indicators and explanatory variables that we use in our empirical analysis. Section 4 outlines our empirical strategy and model specifications. We discuss our main results in Section 5. Finally, Section 6 summarises our findings and relates them to the existing theoretical and empirical evidence.

\section{Theoretical and Empirical Background}

The theoretical starting point for this analysis is the literature on new technology diffusion. $^{2}$ The main prediction of these models is that preferred adoption dates vary across potential adopters of a new technology. To understand the diffusion of ICT as a

\footnotetext{
${ }^{1}$ The share of ICT exports in total exports in Ireland is the highest among the European Union's 27 member states (European Commission, 2009).

${ }^{2}$ Karshenas and Stoneman (1993), Geroski (2000) and Stoneman (2002) provide excellent surveys of new technology diffusion models.
} 
new technology it is therefore essential to uncover the factors that explain the variation in the rates of its adoption and use across firms, industries, regions and countries.

The early models of new technology diffusion known as epidemic models (Mansfield, 1963a,b) assume that the adoption of a new technology depends upon the spread of information about its availability or other "epidemic-type” learning factors which help to reduce the uncertainty related to new technologies. The learning effects are assumed exogenous and the diffusion path is driven by reductions in cost or quality improvements due to the new technology (Stoneman, 2002). At any point in time only a fraction of potential adopters would wish to use, or would be sufficiently informed to use the new technology. The epidemic models predict that the adoption of new technology increases over time as the risk associated with adoption decreases due to learning effects across and within firms (Battisti and Stoneman, 2005).

Another group of theoretical models links the variation in the preferred adoption date to differentials in returns (profitability) to potential adopters of new technologies. Rank (or probit) models (David, 1969; Davies, 1979; Ireland and Stoneman, 1986) point to firm heterogeneity as a driving factor behind differentials in gross returns from using the new technology. Consequently, firms with high returns from the adoption of new technology will be early adopters while firms with low returns will be late adopters. Stock models assume that the benefit to the marginal adopter from acquiring a new technology decreases with the number of previous adopters. Thus for any cost of acquiring the new technology, the adoption will not be profitable beyond a certain number of adopters. The adoption of a new technology is modelled as a strategic decision using a game-theoretic approach (Reinganum, 1981). Order models (Ireland and Stoneman, 1985; Fudenberg and Tirole, 1985) assume that the return to a firm from adopting a new technology depends upon its position in the order of adoption: early adopters achieve a greater return than late adopters. Furthermore the decision of early 
adopters can affect the adoption date of later adopters. It follows that the firm's decision to adopt a new technology takes into account how waiting will affect its profits.

The theoretical literature also distinguishes between inter-firm diffusion - the number of firms using the new technology, and intra-firm diffusion - the intensity of using the new technology by individual firms (Stoneman, 2002; Battisti and Stoneman, 2005). In the case of inter-firm diffusion, the adoption decision leads to a revenue externality, while in the case of intra-firm diffusion, revenue externalities are internalised and appear in the marginal revenue from the adoption of new technology (Stoneman, 2002).

The bulk of existing empirical studies on the determinants of new technology diffusion has focused on inter-firm diffusion or adoption of new technologies by firms, while intra-firm diffusion - the extent of using new technology by firms, has been less investigated (Battisti and Stoneman, 2003, 2005). Empirical evidence suggests that in the earlier stages of adoption inter-firm diffusion prevails, whereas intra-firm diffusion gains importance only later on in the diffusion process (Battisti and Stoneman, 2003). While a large number of empirical studies have focused on a single model of new technology diffusion, Karshenas and Stoneman (1993) estimate an empirical model which captures simultaneously rank, stock, order and epidemic effects. Their findings using data on the diffusion of computer numerically controlled machine tools (CNC) in the UK engineering industry from 1968 to 1980 suggest the presence of rank and epidemic effects, but provide little evidence of stock and order effects

Rank effects have been modelled using variables related to firm characteristics, such as firm size, skill composition of the work force, and organisational structure.

A stylised fact supported by a large empirical literature is that larger firms are more likely to adopt new technologies early. Firm size is commonly used in the empirical literature on new technology adoption because it is easy to observe and it 
serves as a proxy for several things (Geroski, 2000). Large firms can earn higher profits from adopting new technology in comparison to small firms. Given the risks and costs of early adoption they are in a better position to adopt new technology because they have fewer financial constraints and because they are likely to be less risk averse. Large firms might be more motivated and able to innovate in order to pre-empt rivals; also the scope for innovation complementarities is likely to be greater in larger firms. Existing empirical evidence on the relationship between firm size and ICT adoption is mixed. While a number of studies find a positive correlation between firm size and the adoption of ICT (Teo and Tan, 1998; Thong, 1999; Fabiani et al., 2005; Giunta and Trivieri, 2007), other studies find a weak or insignificant relationship (Lefebvre et al., 2005; Love et al., 2005; Teo et al., 1997). Hollenstein (2004) suggests that this relationship might be non-linear. He finds that in a sample of Swiss firms, firm size is positively related to early and intensive use of $\mathrm{ICT}^{3}$ only in firms with up to 200 employees. He also finds that medium-sized companies use the Internet more intensively in comparison to large firms. Battisti et al. (2007) find that while large firms are more likely to adopt ICT in comparison to smaller firms, once they adopted ICT smaller firms are likely to use ICT more intensively than larger firms.

A large theoretical and empirical literature has focused on the relationship between human capital and new technology adoption. One strand of literature focuses on the role of education or skills (human capital) in the process of adopting new technologies and shows that a highly educated workforce facilitates an earlier adoption of new technology (Nelson and Phelps, 1966; Bartel and Lichtenberg, 1987; Chun, 2003). A second strand of the literature focuses on the new technology-skill complementarity and shows that demand for educated workers rises together with the use of the new technology (Griliches, 1969; Berman et al., 1994; Doms et al., 1997; Haskel and Heden,

\footnotetext{
${ }^{3}$ The intensity of ICT use is measured by two variables: the number of ICT elements adopted and the share of employees using the Internet.
} 
1999). Bugamelli and Pagano (2004) report that the lack of investment in human capital and organisational change acted as a barrier to investment in ICT in manufacturing firms in Italy.

Firms facing stronger competition are more inclined to innovate and adopt new technologies, such as ICT, in order to strengthen their performance and chances of survival (Porter, 1990). Several studies show that competitive pressure is positively associated with ICT adoption (Dasgupta et al., 1999; Hollenstein, 2004; Kowtha and Choon, 2001). In contrast, other papers find no significant effect of competitive pressure on ICT adoption (Jeon et al., 2006; Teo et al., 1997; Thong, 1999).

It has been argued that firms exposed to international competition in export markets are more inclined to innovate and adopt new technologies. Hollenstein (2004), Lucchetti and Sterlacchini (2004), Bayo-Moriones and Lera-López (2007) and Giunta and Trivieri (2007) find evidence showing that firms that export are more likely to use ICT . Similarly, foreign-owned firms are more likely to be early adopters of new technology as well as potentially important channels of new technology diffusion (Keller, 2004; Narula and Zanfei, 2005). However, Teo and Ranganathan (2004) find no difference between foreign-owned and domestic plants with respect to the adoption of business-to-business (B2B) electronic commerce in Singapore.

Epidemic effects affecting the adoption of new technologies are linked to characteristics of the environment in which firms operate such as firm density, information and knowledge spillovers, and network externalities. Given the uncertainty about the profitability of a new technology, observing the adoption decision of other firms might play an important role in the decision to adopt new technologies. Hence, information spillover effects from interactions among firms may be important for the adoption of ICT. Baptista (2000) finds that, in the case of a sample of firms from engineering and metalworking industries in the United Kingdom, proximity to early 
adopters of new technology is positively related to learning effects that foster the adoption of new technology. Moreover, there is evidence suggesting that technology diffusion is geographically localised and information spillovers decline as distance between firms increases (Jaffe et al., 1993; Keller, 2002).

Another dimension of epidemic effects that is relevant for ICT adoption relates to the network nature of ICT. On the one hand, being part of a network increases the awareness of the new technology and reduces the risks associated with adopting and using it (Gourlay and Pentecost, 2002). In addition, network externalities are positively related to the number of users of the new technology (Oulton, 2002). On the other hand, the larger the number of firms, the more likely is the occurrence of coordination failures that can slow down the adoption rate (Cooper and John, 1988). At the firm-level networks may be manifest in multi-unit firms.

In contrast to a well established theoretical literature on the diffusion of new technologies, empirical evidence about the diffusion of ICT is scarce and inconclusive. With the exception of Hollenstein (2004) and Battisti et al. (2007) most of existing empirical studies (for example, Fabiani et al. 2005; Jeon et al. 2006; Giunta and Tevieri 2007; Bayo-Moriones and Lera-López 2007) do not test hypotheses derived from theory and do not distinguish between inter- and intra-firm diffusion of ICT. Our paper contributes to filling this gap. In particular, we estimate theory-based models and provide empirical evidence on the determinants of inter- and intra-firm diffusion of ICT across manufacturing firms in Ireland over the period 2001-2004. We also improve on the previous cross-sections studies by using an unbalanced panel which allows us to explain the diffusion of ICT over time and to alleviate potential endogeneity arising from simultaneity and omitted variable bias. 
Our data set is obtained by combining information from two sources. One data source is the 'Survey on E-Commerce and ICT' that has been conducted as part of an EU-wide effort to gain information on ICT use since 2002 on an annual basis by the Central Statistics Office (CSO) in Ireland. The principal variables collected refer to the level of Internet usage, types of connection to the Internet, reasons for using the Internet, sales and purchases via the Internet, and barriers to e-commerce. The second data source is the annual Census of Industrial Production which covers Irish manufacturing and is also collected by the CSO. The census contains information on turnover, exports, employment and earnings for all enterprises and local units with three or more employees.

The two data sets can be merged through the establishment identifier at the enterprise level ${ }^{4}$. The merged data set covers the period 2002-2004 for all variables. All information relating to monetary values (e.g. transactions over the Internet as a share of turnover) in the Survey on E-Commerce and ICT is collected for the year prior to the survey year. As a result this information is available for the period 2001-2004. The combination of the two data sets covers roughly 40 per cent of the enterprises in each year and is representative with respect to the size distribution, the industry classification and the regional distribution of manufacturing activity. In the 2004 data, smaller firms are to some extent underrepresented. As the sample for the e-commerce survey is redrawn every year, the panel is unbalanced, 23\% of the firms are surveyed in all 3 years, $34 \%$ are surveyed in two (not necessarily consecutive) years, and $43 \%$ of firms are surveyed in only 1 year.

\footnotetext{
${ }^{4}$ In this paper we use the terms enterprise and firm interchangeably.
} 
The final working sample includes firms in the core manufacturing industries. ${ }^{5}$ Further, we checked the data for outliers. We define as outliers observations where wages per employee are in the top or bottom $0.25 \%$ of the distribution and also observations that have changes in labour productivity, output growth, wages per employee, the share of sales due to online transactions, the share of clerical employees and the share of managerial and technical employees in the top and bottom $0.5 \%$ of the distribution. We omit all firms that have any outliers according to this definition.

To measure ICT adoption, we construct the following four indicators: Indicators of inter-firm ICT adoption:

- web: 1 if the firm has a website, 0 otherwise;

- $n s: 1$ if the firm accepts online transactions, 0 otherwise.

Indicators of intra-firm ICT diffusion:

- empucomp: the share of employees using a computer in the total number of employees;

- esale: the share of sales (turnover) due to online transactions - carried out via a website, email, and electronic data interchange (EDI).

The left half of Table 1 provides summary statistics related to our indicators of inter-firm ICT adoption, namely the existence of a website, and whether the company accepts online orders. As shown in Table 1, by 2004, 60 per cent of firms had a website. This share is higher for larger and for foreign-owned firms. The regional differences are not very large; the share of firms with a website is highest in the capital city region. The share of firms that accept online orders has increased over the analysed period to just over 15 per cent in the sample. The share of firms that accept or have received online orders is lowest in the group of firms that have between 250 and 499 employees; it is

\footnotetext{
${ }^{5}$ NACE Rev. 1.1 sectors 15-36. Sector 23 (Manufacture of coke, refined petroleum products and nuclear fuel) is excluded for reasons of confidentiality. We also exclude Sector 16 (Tobacco) as this sector is dropped in several regressions due to the small number of observations together with the homogeneity of observations.
} 
highest among the largest firms. There is little difference between the shares of domestic and foreign-owned firms. Shares differ substantially across the different NUTS3 regions, with the greater Dublin area having the highest share of firms with online transactions.

[Insert Table 1 about here]

The right half of Table 1 provides summary statistics of the two indicators of intra-firm ICT diffusion, namely the share of employees using a computer (empucomp) and the share of sales due to online transactions including both transactions over the Internet (website, email) as well as transactions via electronic data interchange (EDI). ICT use is higher in larger firms, and there is a clear time trend over the three- or fouryear period. Both the share of employees using computers and the share of turnover due to online transactions are higher in foreign-owned firms than in domestic firms. Both indicators vary across regions; the regional variation is larger for the share of turnover due to online transactions. The dimensions presented in Table 1 are not independent of one another: over $64 \%$ of foreign firms have 50 or more employees, while nearly $63 \%$ of domestic firms have less than 20 employees. While just over one quarter of firms are located in the Dublin area, the firm size distribution is relatively similar across counties. Proportionately somewhat more foreign-owned firms are located in the Midwest and Southwest. 
Based on the discussion of the theory on new technology adoption in Section 2, we model the adoption of ICT in firm $i$, industry $j$, region $r$, at time $t\left(Y_{i j r t}\right)$ as a function of rank effects and epidemic effects. ${ }^{6}$ The basic model specification is as follows:

$Y_{i j r t}=\alpha+\beta_{1} s 2+\beta_{2} s 3+\beta_{3} s 4+\beta_{4} s 5+\beta_{5} d \ln t o_{i j r, t-1}+\beta_{6} a g g e_{i j r, t-1}+\beta_{7}$ multi $_{i j r, t-1}+\beta_{8}$ foreign $_{i j r, t-1}$ $+\beta_{9} \ln w_{\text {pe }}$ ijr,t-1$+\beta_{10}$ mantech $_{i j r, t-1}+\beta_{11}$ clerical $_{i j r, t-1}+\beta_{12}$ exint $_{i j r, t-1}+\beta_{13}$ conc $_{j r, t-1}$ $+\beta_{14}$ epid_indreg ${ }_{j r, t-1}+\beta_{15}$ epid_ind ${ }_{j r, t-1}+\lambda_{j}+\lambda_{r}+\lambda_{t}+\varepsilon_{i j r t}$

\section{Rank effects}

We group firms into 5 size classes: firms with less than 20 employees (s1), firms with 20-49 employees (s2), firms with 50-249 employees (s3), firms with 250-499 employees (s4) and firms with 500 and more employees (s5) and treat the smallest firms as the reference group. Assuming that large firms are early adopters of ICT or use it more intensively, we expect positive coefficients $\beta_{1}, \beta_{2}, \beta_{3}, \beta_{4}$ on the firm size dummies.

Further rank effects include output growth (dlnto), firm age (age), a dummy variable which indicates whether a firm is a multi-plant firm (multi) and a dummy for foreign ownership. The inclusion of these variables is based on the prior that fastgrowing firms, new firms or firms with outdated equipment are more likely to adopt new technologies or use them more intensively. While we expect to find $\beta_{5}>0$, the sign for $\beta_{6}$ is ambiguous: while older firms may show higher rates of ICT adoption and use due to learning effects, younger firms may be better placed to adopt recent available technologies. Multi-plant enterprises may be more likely to adopt ICT early as they can

\footnotetext{
${ }^{6}$ We are unable to identify stock and order effects as our data set does not contain the initial adoption dates.
} 
spread the cost over several entities and benefit from enhanced communication within the group. A similar argument applies to foreign-owned firms.

As a proxy for human capital we use average wages per employee (wpe). In addition, we control for the skill composition of employees by using the share of managerial and technical staff in all employees (mantech), and the share of clerical staff, including sales representatives, in all employees (clerical). We expect to find that the parameters $\beta_{9}, \beta_{10}, \beta_{11}$ are positive and significantly different from zero.

Export-intensity (exint) is included as a measure of international competitiveness. Firms that export may also find it easier to communicate with customers abroad using information and communication technologies. We expect ICT adoption and diffusion to be positively associated with export intensity. In addition, to proxy the effect of competition in the domestic market on the adoption and diffusion of ICT we add a measure of industry concentration ( conc $_{j t}$ ), the Herfindahl-Hirschman index $(H H I)$ calculated at the 3-digit industry level using data on turnover (to) as follows:

$$
\text { conc }_{j t}=\sum_{j}\left(m s_{i j t}\right)^{2} \text {, where } m s_{i j t}=\frac{t o_{i j t}}{\sum_{i} t o_{j t}} .
$$

If the parameters $\beta_{1}-\beta_{13}$ are significantly different from zero, the hypothesis of the absence of rank effects can be rejected.

\section{Epidemic effects}

Spillover effects from interactions between firms are likely to be important determinants of ICT adoption at the firm level. To estimate epidemic effects we use two variables: the share of ICT adopters in the same industry $\mathrm{j}$ and region $\mathrm{r}$ at time $\mathrm{t}$ (epid_indreg $\mathrm{j}_{\mathrm{jr}}$ ) and the share of ICT adopters in the same industry $j$ located in the rest of the regions $(\bar{r})$ at time $t$ ( epid $_{-}$ind ${ }_{j \mathrm{jt}}$ ). The two variables are calculated as follows: 


$$
e_{\text {epid_indreg }}{ }_{j r t}=\frac{X_{j r t}^{a}}{X_{j r t}} \text {, }
$$

and

$$
\text { epid_ind }_{j r t}=\frac{X_{j t}^{a}-X_{j r t}^{a}}{X_{j t}-X_{j r t}} \text {, }
$$

where $X_{j r t}^{a}$ denotes enterprises that are using ICT in industry $j$, region $r$ at time $t$ and $X_{j r t}$ is the total number of enterprises in industry $j$, region $r$ at time $t$. We calculate these epidemic (spillover) measures based on the number of firms that have a website (epid_indreg_web and epid_ind_web) when the dependent variables are whether the firm has a website (web) and the share of employees using computers (empucomp). In turn, they are based on the number of firms accepting electronic orders (epid_indreg_ns and epid_ind_ns) when the dependent variables are whether a firm accepts online orders (ns) and the share of turnover due to online transactions (esale). If $\beta_{14}$ and/or $\beta_{15}$ are significantly different from zero, the hypothesis of the absence of epidemic learning effects can be rejected.

We control for unobserved industry-, region- and time-specific effects: $\lambda_{\mathrm{j}}, \lambda_{\mathrm{r}}, \lambda_{\mathrm{t}}$, respectively are dummy variables for 20 NACE 2-digit industries, 8 NUTS3 regions and the years in our panel. Definitions, sources and summary statistics of all variables are given in the Appendix.

We estimate equation (1) using a probit estimator when our dependent variables are the binary indicators of inter-firm ICT adoption as it is the case with web and ns. We further estimate a bivariate probit model for web and ns assessing firms' propensities to both have a website and to accept online sales.

In the case of intra-firm ICT adoption, the dependent variables are continuous (empucomp, esale) and they take values between 0 and 1 . While these models could be estimated using OLS, there is no guarantee that the predicted values will lie between 0 
and 1. Using the log-odds transformation would transform the observations to range over all real numbers, thus allowing OLS estimation. However, this transformation still requires the use of ad-hoc transformations to handle data at the extreme values of zero and one. While few observations take on value 1 , we have many observations that are zero. We therefore prefer to use the fractional probit model as proposed by Papke and Wooldridge (1996).

It might be the case that for a number of explanatory variables the firm's decision on their level may not be exogenous to the firm's decision on ICT adoption or the intensity of ICT use. In order to reduce biases from potential endogeneity, all regressors are lagged by one year with respect to the dependent variable. ${ }^{7}$ Ideally we would also like to control for firm fixed effects, however this is not an appealing option as only a non-representative and highly homogenous sample of around $20 \%$ of firms is observed in all years. Finally, in all our regressions the standard errors are adjusted for clustering at the firm level.

\section{$5 \quad$ Empirical Results}

The estimates for whether firms have a website are shown in the left half of Table 2. The models presented in the first two columns are estimated for all firms jointly. In the second column the epidemic effects are added.

The results indicate that all firm size groups are more likely to have a website compared to firms with less than 20 employees. Further, our results indicate that fastgrowing and younger firms are more likely to have a website. The human capital and

\footnotetext{
${ }^{7}$ We are able to do this without losing another year of our short panel because the explanatory variables come from the Census of Industrial Production which collects information for all firms with more than 3 employees in every year. For those epidemic effects based on the share of firms with a website, we are able to use lags without losing a year of data, because the CIP also collects information on whether firms have a website or not since 1999. For those epidemic effects based on the number of firms that accept online orders we have information for 2001 as this relates to monetary information collected for the year before the Survey on E-commerce and ICT is conducted.
} 
employee composition variables (average wage per employee, share of managerial and technical employees, and share of clerical employees) have a positive effect on a firm's propensity to have a website. Exposure to foreign markets as measured by the export intensity has a positive impact on the probability of a firm to have a website. The dummy for foreign ownership indicates that there are no significant differences between the domestic and foreign-owned firms.

There is no evidence of geographic (location) effects on the probability of having a website. The time dummies are significant, indicating a positive time trend in the adoption of websites. The industry dummies are jointly significant. When we include the epidemic effects, we find that when firms are located in the same industry and region with a large share of other firms that have a website they are also more likely to have a website.

The right half of Table 2 shows the estimates for a firm's propensity to accept orders online. There is no evidence of size effects or effects from other firm characteristics; only the share of clerical employees has a positive impact on the propensity of a firm to accept online orders. An important driver is again exposure to export markets. This may reflect that firms that export abroad need to communicate with customers in far-away places, which may be easier with ICT. There is also evidence that exporting is closely correlated with productivity. ${ }^{8}$ As virtually all foreignowned firms in Ireland export a substantial share of their turnover, the variation in this variable comes mostly from the domestic firms both in terms of their propensity to export and their export intensity. This may indicate that only the more productive domestic firms are also more likely to accept online orders. ${ }^{9}$

\footnotetext{
${ }^{8}$ There is evidence for Ireland and a number of other countries that more productive firms are more likely to select into exporting both internationally (The International Study Group on Exports and Productivity, 2008).

${ }^{9}$ When we estimate these regressions for the subsample of foreign-owned firms, the coefficient on the export intensity is not significant.
} 


\section{[Insert Table 2 about here]}

There are significant location effects, in that firms that are located outside the capital city region are less likely to accept orders online. The industry dummies are jointly significant when we do not include the epidemic effects. The epidemic effects here indicate that being in a region and industry where there is a large share of firms that accept online orders has a positive impact on a firm's propensity to accept online orders.

We further examine to what extent firms use both a website and online orders. Table 3 shows the distribution of firms in four groups: firms using a website and accepting online orders; firms accepting online orders but without a website (this is not a contradiction as online orders include email and EDI); firms with a website but not accepting online orders; firms that do not accept online orders and do not have a website.

The sample size for this analysis is smaller in comparison to the previous two regressions because the observations for web and $n s$ come from different years. More than half of the firms in the sample have a website but only about 13 per cent of firms accept online orders and only about 10 per cent of firms have both a website and accept online orders.

[Insert Table 3 about here]

The estimates of the bivariate probit model are shown in Table 5. We restrict attention to the most zealous adopters, i.e. firms that have a website and accept online orders and to the complete non-adopters, i.e. firms that do not have a website and do not accept online orders. Firms with a large share of clerical employees, firms with high export intensities, and firms located in the capital city region are more likely to have a 
website and to accept online orders. Being in the same industry and region where there is a high share of firms that have a website and in the same industry and region where there is a high share of firms that accept online orders has a positive impact on firms to do both, i.e. have a website and accept online orders.

[Insert Table 4 about here]

The second column of Table 4 shows the determinants of not having a website and also not accepting online orders. All firm size groups with more than 20 employees have a lower propensity to fall into this group than firms with less than 20 employees. Firms with high human capital intensities are less likely to fall into this group; the same is true for firms with high export intensities. The negative coefficients on both measures of epidemic effects suggest that this group of mainly small, non-exporting, low humancapital intensity firms might be missing out on the ICT diffusion path.

We next analyse determinants of intra-firm ICT diffusion or the intensity of ICT use within firms. We start by examining the estimates of the share of employees using computers as shown in the left half of Table 5. Intermediate-size firms appear to be somewhat less likely to have a high share of employees using computers than the group of firms with less than 20 employees. Younger firms and foreign-owned firms have a higher propensity to have a high share of employees using computers. Not surprisingly, there are strong positive effects from the average wage per employee and from the share of managerial and technical employees as well as from the share of clerical employees. The export intensity only matters when the spillover effects are not included. There are some location effects; also here some regions have a lower propensity to have a high share of employees using computers than firms located in the Dublin area. The share of employees using computers is positively associated with proximity to firms in an 
industry and region where a high share of firms have a website and with being in the same industry but not the same region where a high share of firms have a website. Here the industry effects are stronger than the industry-region effects. This is plausible when considering that some industries are much better suited for the use of computerised production processes than others.

[Insert Table 5 about here]

The right half of Table 5 shows the estimates for our second measure of the intensity of ICT use, namely the share of turnover due to online transactions. In this case only a few determinants are significant. The two main determinants of a firm's propensity to have a high share of turnover due to online transactions are export intensity and multi-unit status. Being part of a multi-unit enterprise has a negative effect on a firm's propensity to have a high share of turnover due to online transactions. This could reflect the fact that the largest shares of multi-unit enterprises are in NACE sectors 24 (Manufacture of chemicals, chemical products and man-made fibres) and 26 (Manufacture of other non-metallic mineral products), which have among the lowest shares of turnover due to online transactions. Also here there are positive epidemic effects from being in the same industry and region where a large share of firms accepts online orders. In all regressions the industry dummies are jointly significant, pointing towards industry affiliation as an indicator of the share of turnover due to online transactions.

Given the fact that the intensity of ICT diffusion depends on ICT adoption (Battisti and Stoneman 2005) the estimates of determinants of intra-firm ICT diffusion might reflect a sample selection bias. When the dependent variable is the share of employees using computers (empucomp) this is not an issue since by 2004, 96 per cent 
of all enterprises in the data set use computers. To address this concern when the share of turnover due to online transactions is the dependent variable we also estimated a Heckman selection model where selection depends on whether a firm accepts online orders. We model the selection decision as a function of firm size, firm age, the multiunit dummy, industry, region and time characteristics. However, the selection term does not turn out to be significant and the results for the share of turnover due to online transactions do not change qualitatively. ${ }^{10}$

\section{$6 \quad$ Concluding Remarks}

This paper contributes to the empirical analysis of determinants of ICT diffusion. We estimate a model derived from the theory of new technology diffusion and test rank and epidemic effects. In comparison to existing cross-section studies we estimate an improved econometric model using a novel firm-level panel data set of the Irish manufacturing sector. In particular, we provide empirical evidence on factors driving inter-firm ICT adoption (the usage of websites, online orders) and intra-firm ICT use (the share of employees using computers, the share of turnover due to online transactions).

Our results support the hypothesised rank and epidemic effects. We find that the speed of ICT diffusion is influenced by firm characteristics such as firm size, age, skill intensity, exposure to foreign markets and proximity to early adopters of ICT in the same industry and region. The determinants of inter and intra-firm adoption of ICT are broadly similar with the exception of the effect of firm size and foreign ownership. It appears that while larger firms are more likely to be earlier adopters than small firms, small firms use ICT more intensively than medium-sized firms. This result is similar to findings reported by Hollenstein (2004) and Battisti et al. (2007). While the propensity to adopt ICT is not significantly different in foreign-owned firms when compared to

\footnotetext{
${ }^{10}$ Results are not reported but are available from the authors on request.
} 
domestic firms, foreign-owned firms use ICT more intensively than domestic firms. This result is similar to findings of Teo and Ranganathan (2004) in the case of the adoption of business-to-business e-commerce in Singapore and Barbosa and Faria (2006) in the case of advanced manufacturing technologies in Portugal.

With respect to inter-firm adoption of ICT, we find that the propensity to have a website is higher for larger, younger, fast-growing, skill-intensive and export-intensive firms. Similar results using different indicators for ICT adoption are found for the UK (Battisti et al., 2007), Switzerland (Hollenstein, 2004; Battisti et al., 2007), Italy (Fabiani et al., 2005; Giunta and Trivieri, 2007) and Spain (Bayo-Moriones and LeraLópez, 2007).

While firm characteristics matter most for a firm’s propensity to have a website and for the share of employees using computers, for a firm's propensity to accept online orders and for its share of turnover due to online transactions, organisational factors such as being part of a multi-plant enterprise and the share of clerical employees in total employees matter more. Exposure to export markets is an important positive influence for all our measures of inter- and intra-firm ICT diffusion. This finding may capture productivity differences closely associated with exporting as well as ICT facilitating communication between partners in different countries. This result is stronger compared to other studies (Hollenstein, 2004; Giunta and Trivieri, 2007).

The regional variation in ICT adoption and use in our sample may reflect supply effects related to the uneven provision of ICT infrastructure such as broadband access. Epidemic learning or information spreading effects largely at the regional level are crucial in enhancing both the adoption and the intensity of ICT use.

\section{Acknowledgements}

This work makes use of data from the Central Statistics Office, Ireland, which is CSO copyright. The possibility for controlled access to confidential micro data sets on the 
premises of the CSO is provided for in the Statistics Act 1993. The use of CSO data in this work does not imply the endorsement of the CSO in relation to the interpretation or analysis of the data. This work uses research datasets which may not exactly reproduce statistical aggregates published by the CSO. We are grateful to George Hussey, Don Forde and Richard McMahon from the Central Statistics Office (CSO) of Ireland for valuable data related assistance. The paper has been screened by the CSO to ensure that no confidential information is revealed. Financial support from the European Union's RTD $6^{\text {th }}$ Framework Programme (Contract No. CIT5-028818) is gratefully acknowledged. We thank Frances Ruane, John Fitz Gerald, Seán Lyons, Frank Barry, Roberta Capello, Holger Görg, Mary O’Mahony, the editor Mark Taylor, an anonymous referee and participants at research seminars at the Economic and Social Research Institute in Dublin, Bocconi University in Milan, Università delle Marche at Ancona, Centre for European Economics Research (ZEW) in Mannheim, the annual conference of the Royal Economic Society at Warwick University and the annual congress of the European Economic Association in Barcelona for helpful comments and suggestions.

\section{References}

Arvanitis, S. (2005) Computerization, Workplace Organization, Skilled Labour and Firm Productivity: Evidence for the Swiss Business Sector, Economics of Innovation and New Technology, 14(4), 225-249.

Baptista, R. (2000) Do Innovations Diffuse Faster Within Geographical Clusters?, International Journal of Industrial Organization, 18(3), 515-535.

Barbosa, N. and A.P. Faria (2008) Technology Adoption: Does Labour Skill Matter? Evidence from Portuguese Firm-level Data, Empirica, 35, 179-194

Bartel, A. and F.R. Lichtenberg (1987) The Comparative Advantage of Educated Workers in Implementing New Technology, Review of Economics and Statistics, 69(1), 1-11.

Bassanini, A. and S. Scarpetta (2002) Growth, Technological Change, and ICT Diffusion: Recent Evidence from OECD Countries, Oxford Review of Economic Policy, 18(3), 324-344.

Battisti, G. and P. Stoneman (2003) Inter-Firm and Intra-Firm Effects in the Diffusion of New Process Technologies, Research Policy, 32(9) 1641-1655.

Battisti, G. and P. Stoneman (2005) The Intra-Firm Diffusion of New Process Technology, International Journal of Industrial Organization, 23, 1-22.

Battisti, G., H. Hollenstein, P. Stoneman and M. Woerter (2007) Inter- and Intra-Firm Diffusion of ICT in the United Kingdom (UK) and Switzerland (CH). An Internationally Comparative Study Based on Firm-Level Data, Economics of Innovation and New Technology, 16(8), 669-687. 
Bayo-Moriones, A. and F. Lera-López (2007) A Firm Level Analysis of Determinants of ICT Adoption in Spain, Technovation, 27(6-7), 352-366.

Berman, E., J. Bound, Z. Griliches (1994) Changes in the Demand for Skilled Labour within U.S. Manufacturing: Evidence from the Annual Survey of Manufactures, Quarterly Journal of Economics, 109(2), 367-397

Brynjolfsson, E. and L.M. Hitt (2000) Beyond Computation: Information Technology, Organizational Transformation and Business Performance, Journal of Economic Perspectives, 14, 23-48.

Brynjolfsson, E. and L. Hitt (2003) Computing Productivity: Firm Level Evidence, Review of Economics and Statistics, 85(4), 793-808.

Bugamelli, M. and P. Pagano (2004) Barriers to Investment in ICT, Applied Economics, 36, 2275-2286

Chun, H. (2003) Information Technology and the Demand for Educated Workers: Disentangling the Impacts of Adoption versus Use, Review of Economics and Statistics, 85, 1-8.

Cooper, J. and A. John (1998) Coordinating Coordination Failures in Keynesian Models, Quarterly Journal of Economics, 103, 441-464.

Dasgupta, S., D. Agarwal, A. Ioannidis and S. Gopalakrishnan (1999) Determinants of Information Technology Adoption: An Extension of Existing Models to Firms in a Developing Country, Journal of Global Information Management, 7(3), 30-40.

David, P.A. (1969) A Contribution to the Theory of Diffusion, Standford Center for Research in Economic Growth, memorandum No. 71, Standford University.

Davies, S. (1979) The Diffusion of Process Innovations, Cambridge University Press, Cambridge.

Doms, M., T. Dunne and K. Troske (1997) Workers, Wages and Technology, Quarterly Journal of Economics, 112(1), 253-290.

European Commission (2009) Europe’s Digital Competitiveness Report, vol.2: i-2010ICT Country Profiles, http://ec.europa.eu/information_society/eeurope/i2010/index_en.

Fabiani, S., F. Schivardi, S. Trento (2005) ICT Adoption in Italian Manufacturing: Firm Level Evidence, Industrial and Corporate Change, 14(2), 225-249.

Falk, M. (2005) ICT-linked Firm Reorganisation and Productivity Gains, Technovation, 25(11), 1229-1250.

Fudenberg, D. and Tirole, J. (1985) Preemption and Rent Equalization in the Adoption of New Technology, Review of Economic Studies, 52, 383-40

Geroski, P.A. (2000) Models of Technology Diffusion, Research Policy, 29, 603-625.

Giunta, A. and F. Trivieri (2007) Understanding the Determinants of Information Technology Adoption: Evidence from Italian Manufacturing Firms, Applied Economics, 39, 1325-1334

Gourlay, A. and E. Pentecost (2002) The Determinants of Technology Diffusion: Evidence from the UK Financial Sector, Manchester School, 70(2), 185-203.

Griliches, Z. (1969) Capital-Skill Complementarity, Review of Economics and Statistics, 51(4), 465-468 
Haskel, J. and Y. Heden (1999) Computers and the Demand for Skilled Labour: Industry-and Establishment-Level Panel Evidence for the UK, Economic Journal, 109(454), C68-C78.

Hollenstein, H. (2004) Determinants of the Adoption of Information and Communication Technologies, Structural Change and Economic Dynamics, 15(3), 315-342.

Ireland, N. and P.L. Stoneman (1985) Order Effects, Perfect Foresight and Intertemporal Price Discrimination, Recherches Economiques de Louvain, 51, 720.

Ireland, N. and P.L. Stoneman (1986) Technology Diffusion, Expectations and Welfare, Oxford Economic Papers, vol. 38, 283-304.

Jaffe, A., M. Trajtenberg, and R. Henderson (1993) Geographical Localization of Knowledge Spillovers as Evidenced by Patent Citations, Quarterly Journal of Economics, 108(3), 577-98.

Jeon, B.N., K.S. Han, M.J. Lee (2006) Determining Factors for the Adoption of eBusiness: The Case of SMEs in Korea, Applied Economics, 38, 1905-1916

Jorgenson, D.W. and K. Stiroh (2000) Raising the Speed Limit: US Economic Growth in the Information Age, Brookings Papers on Economic Activity, 31, 125-236.

Karshenas, M. and P.L. Stoneman (1993) Rank, Stock, Order, and Epidemic Effects in the Diffusion of New Process Technologies: An Empirical Model, RAND Journal of Economics, 24(4), 503-528.

Keller, W. (2002) Geographical Localisation of International Technology Diffusion, American Economic Review, 92(1), 120-142.

Keller, W. (2004) International Technology Diffusion, Journal of Economic Literature, 42(3), 52-782

Kowtha, N.R. and T.W. Choon (2001) Determinants of Website Development: A Study of Electronic Commerce in Singapore, Information and Management, 39(3), 227-242.

Lehr, B. and F. Lichtenberg (1999) Information Technology and its Impact on Productivity: Firm Level Evidence from Government and Private Data Sources, 1977-1993, Canadian Journal of Economics, 32, 335-62.

Lefebvre L., E. Lefebvre, E. Elia and H. Boek (2005) Exploring B-to-B E-Commerce Adoption Trajectories in Manufacturing SMEs, Technovation 25(12), 14431456.

Love, P.E.D., Z. Irani, C. Standing, C. Lin and J.M. Burn (2005) The Enigma of Evaluation: Benefits, Costs and Risks of IT in Australian Small-Medium-Sized Enterprises, Information and Management 42(7), 947-964.

Lucchetti and Sterlacchini (2004), The Adoption of ICT among SMEs: Evidence from an Italian Survey, Small Business Economics, 23(2), 151-168.

Mansfield, E. (1963a) Intra-firm Rates of Diffusion of an Innovation, Review of Economics and Statistics, 45(4), 348-359.

Mansfield, E. (1963b) The Speed of Response of Firms to New Techniques, Quarterly Journal of Economics, 77(2), 290-309. 
Matteucci, N., M. O’Mahony, C. Robinson and T. Zwick (2005) Productivity, Workplace Performance and ICT: Industry and Firm-Level Evidence for Europe and the US, Scottish Journal of Political Economy, 52(3), 359-386.

Narula, R. and A. Zanfei (2005) Globalization of Innovation: The Role of Multinational Enterprises, in Fagerberg, J., D. Mowery, R. Nelson (eds.), The Oxford Handbook of Innovation, Oxford University Press, New York, 318-345

Nelson, R.R. and E.S. Phelps (1966) Investing in Humans, Technological Diffusion, and Economic Growth, American Economic Review, 56, 69-75.

OECD (2004) The Economic Impact of ICT, Measurement, Evidence and Implications, OECD, Paris.

Oliner, S.D. and D.E. Sichel (2000) The Resurgence of Growth in the Late 1990s: Is Information Technology the Story?, Journal of Economic Perspectives, 14, 3-12.

Oulton, N. (2002) ICT and Productivity Growth in the United Kingdom, Oxford Review of Economic Policy, 18, 363-79.

Papke, L.E. and J. Wooldridge (1996) Econometric Methods for Fractional Response Variables with an Application to 401(k) Plan Participation Rates, Journal of Applied Econometrics 11, 619-632.

Porter, M. (2004) The Competitive Advantage of Nations, New York: Free Press.

Reinganum, J.F. (1981) On the Diffusion of New Technology: A Game Theoretic Approach, Review of Economic Studies, 48, 395-405.

Stiroh, K.J. (2002) Information Technology and the US Productivity Revival: What Do the Industry Data Say?, American Economic Review, 92(5), 1559-1576.

Stoneman, P. (2002) The Economics of Technological Diffusion, Blackwell, Oxford.

Teo, T.S.H., and C. Ranganathan (2004) Adopters and Non-adopters of Business-toBusiness Electronic Commerce in Singapore, Information and Management 42(1), 89-102.

Teo, T.S.H. and M. Tan (1998) An Empirical Study of Adopters and Non-Adopters of the Internet in Singapore, Information and Management 34(6), 339-345.

Teo, T.S.H., M. Tan and W.K. Buk (1997) A Contingency Model of Internet Adoption in Singapore, International Journal of Electronic Commerce 2(2), 95-118.

The International Study Group on Exports and Productivity (2008), Understanding cross-country differences in exporter premia - Comparable evidence for 14 Countries, Review of World Economics (Weltwirtschaftliches Archiv) 144(4), 596-635.

Thong, J.Y.L (1999) An Integrated Model of Information Systems Adoption in Small Business, Journal of Management Information Systems 4(15), 187-214.

Timmer, M. and B. van Ark (2005) Does Information and Communication Technology Drive EU-US Productivity Growth Differentials?, Oxford Economic Papers, 57, 693-716. 
Table 1: Indicators of inter-firm and intra-firm ICT diffusion:

Summary statistics

\begin{tabular}{|c|c|c|c|c|c|c|c|c|c|c|}
\hline & \multicolumn{4}{|c|}{ Indicators of inter-firm ICT adoption } & \multicolumn{6}{|c|}{ Indicators of intra-firm ICT diffusion } \\
\hline & \multirow[t]{2}{*}{ Obs } & \multirow[t]{2}{*}{$\begin{array}{c}\% \text { of firms } \\
\text { with } \\
\text { website }\end{array}$} & \multirow[t]{2}{*}{ Obs } & \multirow{2}{*}{$\begin{array}{c}\text { \% of firms } \\
\text { that accept } \\
\text { orders } \\
\text { online }\end{array}$} & \multirow[t]{2}{*}{ Obs } & \multicolumn{2}{|c|}{$\begin{array}{c}\text { \% of employees } \\
\text { using } \\
\text { computers }\end{array}$} & \multirow[t]{2}{*}{ Obs } & \multicolumn{2}{|c|}{$\begin{array}{l}\text { \% of turnover } \\
\text { due to online } \\
\text { transactions }\end{array}$} \\
\hline & & & & & & Mean & StdDev & & Mean & StdDev \\
\hline \multicolumn{11}{|l|}{ Year } \\
\hline 2002 & 1,687 & 42.44 & 2,143 & 10.78 & 1,687 & 31.6 & 29.2 & 2,143 & 1.19 & 6.72 \\
\hline 2003 & 2,169 & 47.44 & 1,636 & 14.06 & 2,050 & 33.9 & 29.6 & 1,636 & 1.83 & 8.71 \\
\hline 2004 & 1,444 & 60.39 & 1,236 & 15.13 & 1,444 & 35.9 & 29.1 & 1,236 & 2.08 & 9.25 \\
\hline \multicolumn{11}{|l|}{ Size } \\
\hline$<20$ & 2,922 & 36.82 & 2,572 & 12.33 & 2,871 & 30.8 & 29.5 & 2,572 & 1.44 & 7.35 \\
\hline $20-49$ & 1,235 & 56.84 & 1,253 & 13.73 & 1,202 & 33.3 & 27.8 & 1,253 & 1.19 & 5.11 \\
\hline $50-249$ & 933 & 70.53 & 946 & 13.64 & 905 & 39.2 & 28.9 & 946 & 2.13 & 9.90 \\
\hline $250-499$ & 135 & 84.44 & 154 & 10.39 & 131 & 52.0 & 28.9 & 154 & 3.71 & 16.59 \\
\hline $500+$ & 75 & 89.33 & 90 & 15.56 & 72 & 53.4 & 27.1 & 90 & 3.74 & 14.71 \\
\hline \multicolumn{11}{|c|}{ Ownership } \\
\hline Domestic & 4,475 & 45.23 & 4,141 & 12.97 & 4,381 & 30.9 & 28.3 & 4,141 & 1.39 & 6.90 \\
\hline Foreign & 825 & 71.88 & 874 & 12.70 & 800 & 49.1 & 30.5 & 874 & 2.70 & 12.14 \\
\hline \multicolumn{11}{|c|}{ NUTS3 region } \\
\hline Border & 726 & 46.97 & 670 & 12.54 & 709 & 25.5 & 24.9 & 670 & 2.22 & 9.80 \\
\hline Midlands & 308 & 44.81 & 289 & 9.34 & 302 & 26.0 & 22.6 & 289 & 0.72 & 4.25 \\
\hline West & 476 & 50.21 & 436 & 15.14 & 469 & 34.5 & 30.0 & 436 & 1.35 & 6.39 \\
\hline Dublin & 1,370 & 54.01 & 1,259 & 17.55 & 1,331 & 42.6 & 32.7 & 1,259 & 1.86 & 7.45 \\
\hline Mideast & 538 & 49.26 & 539 & 12.24 & 530 & 33.0 & 28.3 & 539 & 1.80 & 9.44 \\
\hline Midwest & 443 & 48.53 & 449 & 11.80 & 432 & 33.3 & 29.2 & 449 & 1.26 & 5.23 \\
\hline Southeast & 692 & 44.80 & 687 & 8.73 & 680 & 28.6 & 26.0 & 687 & 1.19 & 8.44 \\
\hline Southwest & 747 & 49.40 & 686 & 10.35 & 728 & 33.6 & 28.7 & 686 & 1.67 & 9.38 \\
\hline Total & 5,300 & 49.38 & 5,015 & 12.92 & 5,181 & 33.7 & 29.4 & 5,015 & 1.62 & 8.08 \\
\hline
\end{tabular}

Note: The number of firms per year differs for the different indicators because all turnover-related information is collected for the year prior to the year when the Survey on E-commerce and ICT was conducted (see Section 3 for more details on data from the Survey on E-commerce and ICT). 
Table 2: $\quad$ Determinants of inter-firm ICT adoption: Probit estimates

\begin{tabular}{|c|c|c|c|c|c|c|c|c|c|c|c|c|}
\hline \multirow{2}{*}{ rank effects } & \multicolumn{6}{|c|}{ firm's propensity to have a website } & \multicolumn{6}{|c|}{ firm's propensity to accept online orders } \\
\hline & & & & & & & & & & & & \\
\hline s2(20-49) & 0.154 & $(0.027)$ & $* * *$ & 0.157 & $(0.027)$ & $* * *$ & -0.008 & $(0.016)$ & & -0.006 & $(0.016)$ & \\
\hline s3(50-249) & 0.252 & $(0.032)$ & $* * *$ & 0.246 & $(0.033)$ & $* * *$ & -0.014 & $(0.021)$ & & -0.013 & $(0.020)$ & \\
\hline s4(250-499) & 0.317 & $(0.057)$ & $* * *$ & 0.261 & $(0.068)$ & $* * *$ & -0.045 & $(0.033)$ & & -0.048 & $(0.030)$ & \\
\hline s5(500+) & 0.360 & $(0.074)$ & $* * *$ & 0.336 & $(0.080)$ & $* * *$ & -0.019 & $(0.050)$ & & -0.031 & $(0.041)$ & \\
\hline dlnto & 0.055 & $(0.026)$ & $* *$ & 0.054 & $(0.026)$ & $* *$ & 0.016 & $(0.017)$ & & 0.015 & $(0.017)$ & \\
\hline age & -0.001 & $(0.001)$ & & -0.001 & $(0.001)$ & $*$ & 0.001 & $(0.000)$ & & 0.000 & $(0.000)$ & \\
\hline multi & 0.091 & $(0.072)$ & & 0.074 & $(0.073)$ & & 0.024 & $(0.040)$ & & 0.032 & $(0.040)$ & \\
\hline foreign & -0.055 & $(0.041)$ & & -0.069 & $(0.042)$ & & -0.025 & $(0.022)$ & & -0.023 & $(0.020)$ & \\
\hline lnwpe & 0.162 & $(0.033)$ & $* * *$ & 0.159 & $(0.033)$ & $* * *$ & -0.002 & $(0.019)$ & & 0.001 & $(0.019)$ & \\
\hline mantech & 0.437 & $(0.097)$ & $* * *$ & 0.380 & $(0.097)$ & $* * *$ & 0.077 & $(0.050)$ & & 0.065 & $(0.048)$ & \\
\hline clerical & 0.637 & $(0.089)$ & $* * *$ & 0.526 & $(0.092)$ & $* * *$ & 0.107 & $(0.045)$ & $* *$ & 0.085 & $(0.043)$ & $* *$ \\
\hline exint & 0.155 & $(0.043)$ & $* * *$ & 0.117 & $(0.044)$ & $* * *$ & 0.077 & $(0.025)$ & $* * *$ & 0.063 & $(0.023)$ & $* * *$ \\
\hline conc & 0.257 & $(0.133)$ & $*$ & 0.044 & $(0.149)$ & & 0.014 & $(0.081)$ & & -0.021 & $(0.077)$ & \\
\hline epidemic effects & & & & & & & & & & & & \\
\hline epid_indreg_web & & & & 0.730 & $(0.064)$ & $* * *$ & & & & & & \\
\hline epid_ind_web & & & & -0.109 & $(0.101)$ & & & & & & & \\
\hline epid_indreg_ns & & & & & & & & & & 0.283 & $(0.038)$ & $* * *$ \\
\hline epid_ind_ns & & & & & & & & & & 0.120 & $(0.074)$ & \\
\hline other controls & & & & & & & & & & & & \\
\hline border & 0.013 & $(0.038)$ & & 0.059 & $(0.038)$ & & -0.039 & $(0.018)$ & $* *$ & -0.033 & $(0.018)$ & $*$ \\
\hline midlands & -0.028 & $(0.053)$ & & 0.018 & $(0.054)$ & & -0.072 & $(0.017)$ & $* * *$ & -0.058 & $(0.019)$ & $* * *$ \\
\hline west & 0.026 & $(0.042)$ & & 0.059 & $(0.042)$ & & -0.019 & $(0.022)$ & & -0.016 & $(0.021)$ & \\
\hline mideast & -0.026 & $(0.041)$ & & 0.008 & $(0.042)$ & & -0.045 & $(0.019)$ & $* *$ & -0.039 & $(0.019)$ & $* *$ \\
\hline midwest & -0.031 & $(0.046)$ & & 0.012 & $(0.046)$ & & -0.044 & $(0.019)$ & $* *$ & -0.032 & $(0.020)$ & \\
\hline southeast & -0.036 & $(0.037)$ & & 0.004 & $(0.038)$ & & -0.065 & $(0.016)$ & $* * *$ & -0.055 & $(0.016)$ & $* * *$ \\
\hline southwest & 0.017 & $(0.037)$ & & 0.019 & $(0.038)$ & & -0.056 & $(0.016)$ & $* * *$ & -0.048 & $(0.016)$ & $* * *$ \\
\hline 2003 & 0.053 & $(0.011)$ & $* * *$ & 0.033 & $(0.012)$ & $* * *$ & 0.035 & $(0.011)$ & $* * *$ & 0.035 & $(0.012)$ & $* * *$ \\
\hline 2004 & 0.130 & $(0.016)$ & $* * *$ & 0.100 & $(0.018)$ & $* * *$ & 0.048 & $(0.014)$ & $* * *$ & 0.029 & $(0.014)$ & $* *$ \\
\hline Ind $\chi^{\wedge} 2[\mathrm{p}]$ & 44.76 & {$[0.00]$} & & 32.14 & [0.03] & & 46.02 & {$[0.00]$} & & 17.28 & {$[0.57]$} & \\
\hline Obs/Firms & 4859 & 2625 & & 4859 & 2625 & & 3993 & 2298 & & 3993 & 2298 & \\
\hline LogL & & 56.8 & & -27 & 34.0 & & -14 & 4.2 & & -144 & 0.9 & \\
\hline$\chi^{\wedge} 2$ & & 1.9 & & & 4.0 & & 13 & & & 20 & & \\
\hline $\mathrm{R} \wedge 2$ pseudo & & 15 & & & 19 & & 0. & & & 0.0 & & \\
\hline
\end{tabular}


Table 3: $\quad$ Number of firms with a website and online orders

\begin{tabular}{crccc}
\hline & & \multicolumn{3}{c}{ firm accepts online orders } \\
& & 0 & 1 & sum \\
\hline firm has a & 0 & 1,303 & 104 & 1,407 \\
website & 1 & 1,174 & 286 & 1,460 \\
& sum & 2,477 & 390 & 2,867 \\
\hline
\end{tabular}

Table 4: Determinants of inter-firm ICT adoption: bivariate probit estimates of having a website and accepting online orders

\begin{tabular}{|c|c|c|c|c|c|c|}
\hline \multirow{2}{*}{ rank effects } & \multicolumn{3}{|c|}{$\mathrm{ns}=1$, web $=1$} & \multicolumn{3}{|c|}{$\mathrm{ns}=0$, web $=0$} \\
\hline & & & & & & \\
\hline s2(20-49) & 0.002 & $(0.014)$ & & -0.131 & $(0.032)$ & $* * *$ \\
\hline s3(50-249) & -0.006 & $(0.018)$ & & -0.232 & $(0.039)$ & $* * *$ \\
\hline s4(250-499) & -0.035 & $(0.032)$ & & -0.228 & $(0.089)$ & $* * *$ \\
\hline s5(500+) & -0.023 & $(0.040)$ & & -0.263 & $(0.104)$ & $* *$ \\
\hline dlnto & 0.014 & $(0.015)$ & & -0.029 & $(0.036)$ & \\
\hline age & 0.000 & $(0.000)$ & & 0.001 & $(0.001)$ & \\
\hline multi & 0.009 & $(0.040)$ & & -0.095 & $(0.091)$ & \\
\hline foreign & -0.005 & $(0.018)$ & & 0.076 & $(0.049)$ & \\
\hline lnwpe & 0.018 & $(0.017)$ & & -0.128 & $(0.041)$ & $* * *$ \\
\hline mantech & 0.039 & $(0.044)$ & & -0.382 & $(0.121)$ & $* * *$ \\
\hline clerical & 0.105 & $(0.042)$ & $* *$ & -0.504 & $(0.112)$ & $* * *$ \\
\hline exint & 0.049 & $(0.020)$ & $* *$ & -0.166 & $(0.053)$ & $* * *$ \\
\hline conc & -0.003 & $(0.072)$ & & -0.128 & $(0.190)$ & \\
\hline \multicolumn{7}{|l|}{ epidemic effects } \\
\hline epid_indreg_ns & 0.252 & $(0.035)$ & $* * *$ & -0.166 & $(0.087)$ & $*$ \\
\hline epid_ind_ns & 0.093 & $(0.065)$ & & -0.039 & $(0.161)$ & \\
\hline epid_indreg_web & 0.086 & $(0.032)$ & $* * *$ & -0.640 & $(0.078)$ & $* * *$ \\
\hline epid_ind_web & 0.011 & $(0.053)$ & & 0.150 & $(0.131)$ & \\
\hline \multicolumn{7}{|l|}{ other controls } \\
\hline border & -0.011 & $(0.017)$ & & -0.038 & $(0.046)$ & \\
\hline midlands & -0.064 & $(0.013)$ & $* * *$ & -0.011 & $(0.068)$ & \\
\hline west & -0.019 & (0.019) & & -0.011 & $(0.052)$ & \\
\hline mideast & -0.026 & $(0.017)$ & & 0.015 & $(0.050)$ & \\
\hline midwest & -0.012 & $(0.020)$ & & 0.019 & $(0.057)$ & \\
\hline southeast & -0.039 & $(0.014)$ & $* * *$ & 0.032 & $(0.046)$ & \\
\hline southwest & -0.033 & $(0.015)$ & $* *$ & 0.028 & $(0.047)$ & \\
\hline 2003 & 0.029 & $(0.010)$ & $* * *$ & -0.039 & $(0.016)$ & $* *$ \\
\hline 2004 & 0.028 & $(0.013)$ & $* *$ & -0.088 & $(0.024)$ & $* * *$ \\
\hline Ind $\chi^{\wedge} 2[\mathrm{p}]$ & & 56.54 & & {$[0.03]$} & & \\
\hline Obs/Firms & & 2867 & & 1667 & & \\
\hline $\log L$ & & -2596.0 & & & & \\
\hline$\chi^{\wedge} 2$ & & 603.3 & & & & \\
\hline
\end{tabular}


Table 5: $\quad$ Determinants of intra-firm ICT diffusion: Fractional probit estimates

\begin{tabular}{|c|c|c|c|c|c|c|c|c|c|c|c|c|}
\hline \multirow[b]{2}{*}{ rank effects } & \multicolumn{6}{|c|}{ share of employees using computers } & \multicolumn{6}{|c|}{ share of turnover due to online transactions } \\
\hline & & & & & & & & & & & & \\
\hline s2(20-49) & -0.022 & $(0.012)$ & $*$ & -0.020 & $(0.012)$ & & -0.005 & $(0.003)$ & $*$ & -0.004 & $(0.002)$ & $*$ \\
\hline s3(50-249) & -0.023 & $(0.015)$ & & -0.026 & $(0.015)$ & $*$ & 0.001 & $(0.004)$ & & 0.001 & $(0.003)$ & \\
\hline s4(250-499) & 0.023 & $(0.027)$ & & 0.009 & $(0.026)$ & & 0.004 & $(0.012)$ & & 0.002 & $(0.009)$ & \\
\hline s5(500+) & 0.017 & $(0.038)$ & & 0.004 & $(0.038)$ & & 0.018 & $(0.022)$ & & 0.012 & $(0.016)$ & \\
\hline dlnto & -0.008 & $(0.014)$ & & -0.010 & $(0.014)$ & & 0.003 & $(0.004)$ & & 0.003 & $(0.004)$ & \\
\hline age & -0.001 & $(0.000)$ & $* *$ & -0.001 & $(0.000)$ & $* * *$ & 0.000 & $(0.000)$ & & 0.000 & $(0.000)$ & \\
\hline multi & 0.008 & $(0.025)$ & & -0.001 & $(0.024)$ & & -0.008 & $(0.003)$ & $* *$ & -0.007 & $(0.003)$ & $* * *$ \\
\hline foreign & 0.079 & $(0.018)$ & $* * *$ & 0.074 & $(0.018)$ & $* * *$ & -0.002 & $(0.004)$ & & -0.001 & $(0.003)$ & \\
\hline lnwpe & 0.119 & $(0.017)$ & $* * *$ & 0.117 & $(0.017)$ & $* * *$ & 0.000 & $(0.004)$ & & 0.001 & $(0.003)$ & \\
\hline mantech & 0.427 & $(0.050)$ & $* * *$ & 0.390 & $(0.050)$ & $* * *$ & 0.016 & $(0.009)$ & $*$ & 0.013 & $(0.008)$ & \\
\hline clerical & 0.565 & $(0.041)$ & $* * *$ & 0.497 & $(0.041)$ & $* * *$ & 0.003 & $(0.007)$ & & 0.001 & $(0.007)$ & \\
\hline exint & 0.050 & $(0.018)$ & $* * *$ & 0.029 & $(0.018)$ & & 0.017 & $(0.004)$ & $* * *$ & 0.013 & $(0.003)$ & $* * *$ \\
\hline conc & 0.113 & $(0.054)$ & $* *$ & -0.029 & $(0.057)$ & & 0.004 & $(0.017)$ & & -0.002 & $(0.014)$ & \\
\hline \multicolumn{13}{|l|}{ epidemic effects } \\
\hline epid_indreg_web & & & & 0.109 & $(0.027)$ & $* * *$ & & & & & & \\
\hline epid_ind_web & & & & 0.282 & $(0.046)$ & $* * *$ & & & & & & \\
\hline epid_indreg_ns & & & & & & & & & & 0.045 & $(0.008)$ & $* * *$ \\
\hline epid_ind_ns & & & & & & & & & & 0.012 & $(0.012)$ & \\
\hline other controls & & & & & & & & & & & & \\
\hline border & -0.056 & $(0.016)$ & $* * *$ & -0.052 & $(0.016)$ & $* * *$ & 0.003 & $(0.005)$ & & 0.004 & $(0.004)$ & \\
\hline midlands & -0.048 & $(0.020)$ & $* *$ & -0.043 & $(0.020)$ & $* *$ & -0.006 & $(0.004)$ & & -0.003 & $(0.004)$ & \\
\hline west & 0.009 & $(0.021)$ & & 0.010 & $(0.021)$ & & -0.003 & $(0.003)$ & & -0.002 & $(0.003)$ & \\
\hline mideast & -0.020 & $(0.019)$ & & -0.014 & $(0.019)$ & & -0.003 & $(0.004)$ & & -0.001 & $(0.003)$ & \\
\hline midwest & -0.018 & $(0.019)$ & & -0.018 & $(0.019)$ & & -0.005 & $(0.003)$ & $*$ & -0.003 & $(0.003)$ & \\
\hline southeast & -0.041 & $(0.017)$ & $* *$ & -0.036 & $(0.017)$ & $* *$ & -0.004 & $(0.004)$ & & -0.004 & $(0.003)$ & \\
\hline southwest & -0.014 & $(0.016)$ & & -0.020 & $(0.016)$ & & -0.002 & $(0.004)$ & & -0.001 & $(0.004)$ & \\
\hline 2003 & 0.013 & $(0.007)$ & $*$ & 0.001 & $(0.007)$ & & 0.006 & $(0.002)$ & $* * *$ & 0.006 & $(0.002)$ & $* * *$ \\
\hline 2004 & 0.006 & $(0.008)$ & & -0.014 & $(0.008)$ & $*$ & 0.006 & $(0.002)$ & $* * *$ & 0.003 & $(0.002)$ & \\
\hline Ind $\chi^{\wedge} 2[\mathrm{p}]$ & 242.15 & {$[0.00]$} & & 172.76 & {$[0.00]$} & & 37.21 & {$[0.01]$} & & 33.08 & {$[0.02]$} & \\
\hline Obs/Firms & 4742 & 2625 & & 4742 & 2625 & & 3993 & 2298 & & 3993 & 2298 & \\
\hline LogL & \multicolumn{2}{|c|}{-2045.4} & \multicolumn{4}{|c|}{-2028.8} & \multicolumn{2}{|c|}{-279.1} & \multicolumn{4}{|c|}{-266.9} \\
\hline$\chi^{\wedge} 2$ & \multicolumn{2}{|c|}{1370.8} & \multicolumn{3}{|c|}{1452.2} & & \multicolumn{2}{|c|}{118.2} & \multicolumn{4}{|c|}{146.9} \\
\hline
\end{tabular}


Appendix:

Description of Variables and Summary Statistics

\begin{tabular}{|c|c|c|c|c|}
\hline Variable & Description & Source & Mean & StdDev \\
\hline web & 1 if firm has a website; 0 otherwise & ECS & 0.494 & 0.500 \\
\hline ns & 1 if firm accepts online orders; 0 otherwise ${ }^{a}$ & ECS & 0.129 & 0.335 \\
\hline empucomp & share of employees using a computer & ECS & 0.337 & 0.294 \\
\hline esale & $\begin{array}{l}\text { share of turnover due to transactions over the } \\
\text { internet including website, email and electronic } \\
\text { data interchange (EDI) - based mainly on the ECS, } \\
\text { information from the CIP is used to fill in missing } \\
\text { years where possible and for consistency checks } \\
\text { between the two datasets }\end{array}$ & $\mathrm{ECS}+\mathrm{CIP}$ & 0.016 & 0.081 \\
\hline s1-s5 & $\begin{array}{l}\text { firm size groups based on the number of persons } \\
\text { engaged }\end{array}$ & CIP & $55.47^{\mathrm{b}}$ & $154.85^{\mathrm{b}}$ \\
\hline dlnto & turnover growth rate ${ }^{c}$ & CIP & 0.016 & 0.301 \\
\hline age & $\begin{array}{l}\text { firm age (earliest year of incorporation recorded is } \\
1900 \text { ) }\end{array}$ & CIP & 17.51 & 17.65 \\
\hline multi & 1 if enterprise has more than one plant; 0 otherwise & CIP & 0.033 & 0.178 \\
\hline foreign & $\begin{array}{l}1 \text { if enterprise's ultimate beneficial owner is located } \\
\text { abroad }\end{array}$ & CIP & 0.156 & 0.363 \\
\hline lnwpe & wages per employee $^{c}$ & CIP & 3.045 & 0.394 \\
\hline mantech & share of managerial and technical employees & CIP & 0.145 & 0.127 \\
\hline clerical & share of clerical employees & CIP & 0.131 & 0.138 \\
\hline exint & share of turnover exported & CIP & 0.245 & 0.362 \\
\hline conc & $\begin{array}{l}\text { Herfindahl-Hirschman index computed at 3-digit } \\
\text { NACE level }\end{array}$ & CIP & 0.072 & 0.121 \\
\hline epid_indreg_web & $\begin{array}{l}\text { share of firms with a website in all firms in the } \\
\text { same 2-digit NACE sector and NUTS3-region }\end{array}$ & CIP & 0.485 & 0.242 \\
\hline epid_ind_web & $\begin{array}{l}\text { share of firms with a website in all firms in the } \\
\text { same 2-digit NACE sector but not in the same } \\
\text { NUTS3-region }\end{array}$ & CIP & 0.472 & 0.178 \\
\hline epid_indreg_ns & $\begin{array}{l}\text { share of firms accepting online orders in the same } \\
\text { 2-digit NACE sector and NUTS3-region }\end{array}$ & $\mathrm{ECS}+\mathrm{CIP}$ & 0.118 & 0.171 \\
\hline epid_ind_ns & $\begin{array}{l}\text { share of firms accepting online orders in the same } \\
\text { 2-digit NACE sector but not in the same NUTS3- } \\
\text { region }\end{array}$ & ECS+CIP & 0.113 & 0.095 \\
\hline \multicolumn{5}{|c|}{ a Replaced to 1 if equal to zero and esale had positive value. } \\
\hline b & persons engaged. & & & \\
\hline
\end{tabular}

